\title{
Mixed Tumor of the Appendix: A Rare Tumor Association
}

\author{
Pierlesky Elion Ossibi*, Mehdi Benkoukous, Abdoul Aliou Zabeirou Oudou, \\ KarimIbn Majdoub, Imane Toughrai, Said AitLaalim, Khalid Mazaz \\ Visceral Surgery Department, Hassan II University Hospital, Fez, Morocco \\ Email: "oselion@yahoo.fr
}

Received 25 August 2014; revised 20 September 2014; accepted 15 October 2014

Copyright (C) 2014 by authors and Scientific Research Publishing Inc.

This work is licensed under the Creative Commons Attribution International License (CC BY). http://creativecommons.org/licenses/by/4.0/

c) (7) Open Access

\begin{abstract}
Malignant tumors of the appendix are rare. They are present in $0.1 \%$ to $0.5 \%$ of appendectomy specimens: confirmed upon histological analysis. Mixed tumors in the appendix are exceptional. We report a mixed mucinous cystadenoma with a moderately differentiated adenocarcinoma of the appendix in a 64-year-old patient presented to the emergency room with bowel obstruction syndrome.
\end{abstract}

Keywords

Tumor, Appendicitis, Mixed

\section{Introduction}

Malignant tumors of the appendix are rare. They are present in $0.1 \%$ to $0.5 \%$ of appendectomy specimens [1] [2]; clinical symptoms are nonspecific. Their preoperative detection is exceptional, despite the immense contribution of medical imaging, and their diagnosis histological. Neuroendocrine tumors are the most common, followed by adenocarcinomas. Tumor associations at Appendix are exceptional. Thus, we report the case of a 64 years old patient with no notable clinical history admitted to the emergency ward for an obstructive bowel syndrome with per operative discovery of a tumor of the appendix, taking up the cecum, perforated at its tip, for which histology analysis returned for a mucinous cystadenoma associated with a moderately differentiated adenocarcinoma of the appendix.

\section{Case Report}

64-year-old male, smoker with no history of disease presented with 3-day history of abdominal pain, bloating Corresponding author.

How to cite this paper: Ossibi, P.E., Benkoukous, M., Oudou, A.A.Z., Majdoub, K., Toughrai, I., AitLaalim, S. and Mazaz, K. (2014) Mixed Tumor of the Appendix: A Rare Tumor Association. Surgical Science, 5, 483-486. 
and constipation with intermittent vomiting. On physical examination, patient was fairly well with a distended and tympanic abdomen. Laboratory tests were normal.

Plain abdominal X-ray revealed air-fluid levels in the small bowel.

Abdominal CT scan showed a small bowel obstruction upstream of an irregular circumferential thickening of the last ileal loop (Figure 1).

The patient was admitted to the emergency surgical unit with per operative discovery of a tumor mass of appendix taking up the cecum, perforated at the tip with the presence of the gelatinous liquid at this level (Figure 2(A) and Figure 2(B)) as well as extensive peritoneal carcinomatosis involving mesentery and parietal peritoneum. An Ileocaecal resection was performed and a Bouilly-Volkmann type stoma made.

Histological examination of the surgical specimen showed a mucinous cystadenoma associated with a moderately differentiated adenocarcinoma of the appendix (Figure 3).

The patient was referred to oncology for chemotherapy.

\section{Discussion}

Primitive malignant tumors of the appendix are rare and occur in $0.1 \%$ to $0.5 \%$ of appendectomy specimens [1] [2]. Their clinical symptoms are nonspecific; clinical presentation is dominated by an appendicular syndrome and/or acute appendicitis, abdominal pain or even fortuitously. The existence of such tumors, potentially serious is always to be considered and should lead to careful histopathological examination of all appendectomy specimens.

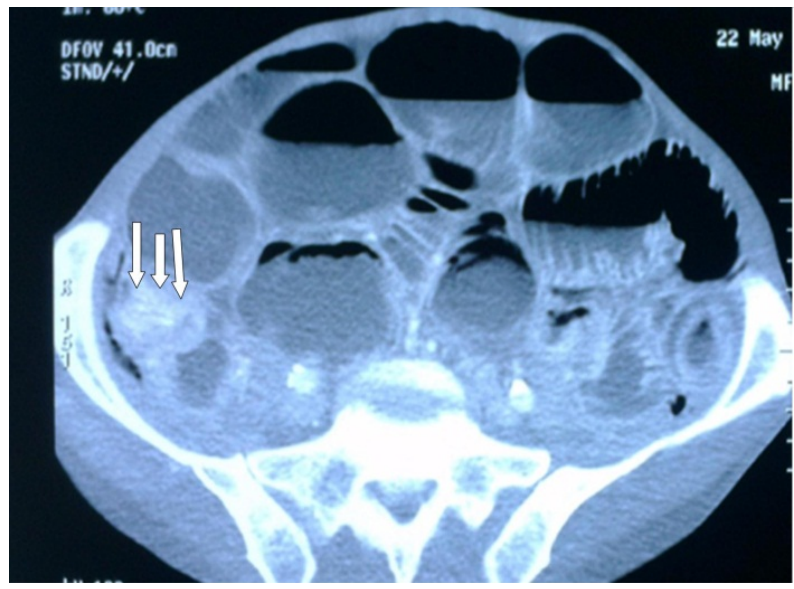

Figure 1. CT showing last ileal loop thickening with upstream small bowel distension.
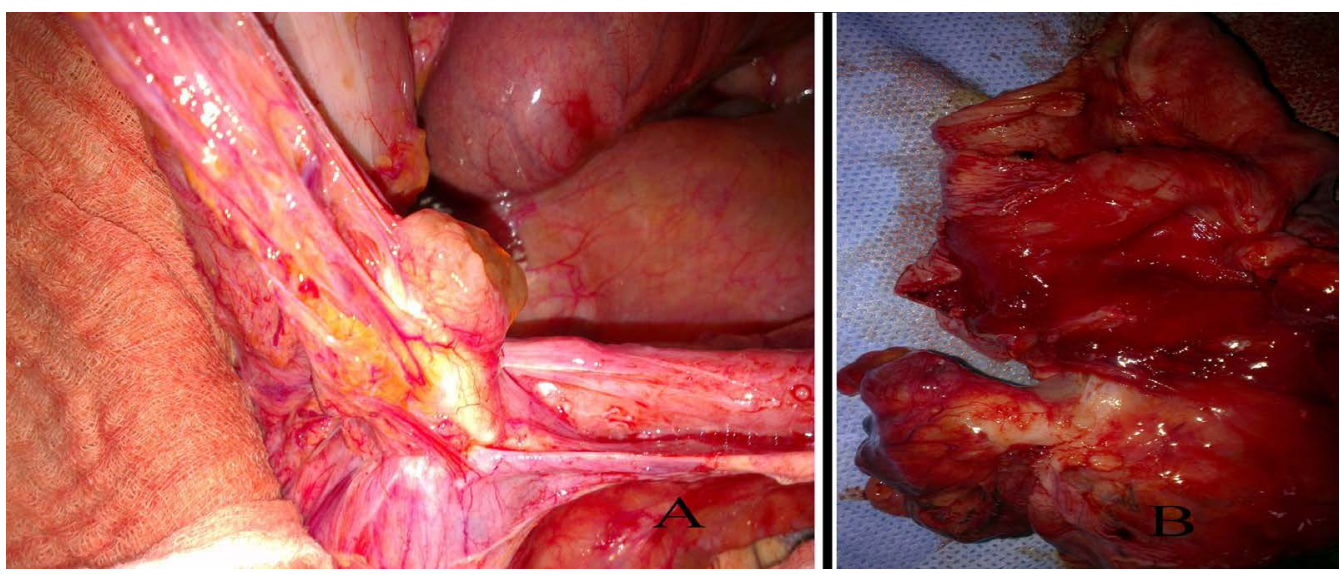

Figure 2. (A) per operative discovery of appendicular tumor perforated at its tip with surrounding gelatinous fluid (B) image showing caecal infiltration of the appendicular tumor. 


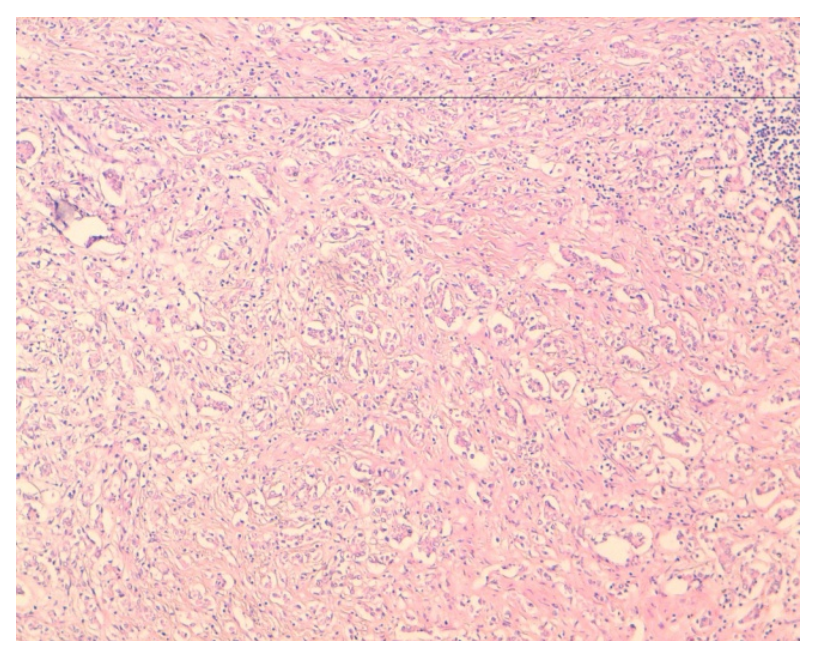

Figure 3. Carcinomatous proliferation made up of glands and cordons with irregular and hyper chromatic nuclei; (HES ×10).

The malignant appendicular proliferations may take several varieties with double differentiation comprising endocrine and exocrine components [3].

-Firstly, the amphicrines carcinomas: exceptional, are defined by the proliferation of a single cell type, which has phenotypic characteristics of both exocrine (mucosecretion) and endocrine (expression of chromogranin A, synaptophysin, NSE...).

-Secondly, the mixed tumors: they combine two cell types, one endocrine, and the other exocrine. These are the:

- Conventional adenocarcinomas with scattered benign endocrine cells;

- The adenocarcinoids combining a predominant adenocarcinomatous component with other malignant endocrine component, each of which can metastasize independently of the other. This type of tumoris derived from a pluripotent cell malignancy [4] transformation;

- Exceptional mixed collision tumors, corresponding to the "embedding" of two different tumors juxtaposed to one another exocrine and endocrine. This again may take two forms:

*Tubular: less mucosecreting and resembling glandular structures,

*Either goblet cells or "goblet cell tumor": with adenocarcinomatous mucosecreting cells isolated in pools of mucus or regrouped into glands [5] [6]. The minority endocrine component may go unnoticed on histological examination.

Surgical treatment of such tumors is not well codified, but for most authors, a simple appendectomy appears to be sufficient for carcinoid tumors; right hemicolectomy is indicated in carcinoid tumors greater than $2 \mathrm{~cm}$ or infiltrating the base of the appendix and in adenocarcinomas [1].

Mixed appendicular tumors are very rare and may have variable clinical presentations. In our case, patient presented with an appendicular tumor infiltrating the cecum. The curative surgical treatment would have been a right hemicolectomy but an ileo-cecal resection was performed due to the presence of peritoneal carcinomatosis.

The prognosis of appendicular tumors depends on the histological type, tumor size and degree of parietal infiltration [7].

\section{Conclusion}

Malignant tumors of the appendix are rare. Their diagnosis is histological. Surgical treatment is not well codified and the prognosis depends on the histological type, tumor size and the degree of parietal infiltration.

\section{References}

[1] Connor, S.J., Hanna, G.B. and Frizelle, F.A. (1998) Appendiceal Tumors: Retrospective Clinicopathologic Analysis of Appendiceal Tumors from 7,970 Appendectomies. Diseases of the Colon \& Rectum, 41, 75-80. http://dx.doi.org/10.1007/BF02236899 
[2] Parkes, S.E., Muir, K.R., Alsheyyab, M., Cameron, A.H., Pincott, J.R., Raafat, F., et al. (1993) Carcinoid Tumours of the Appendix in Children 1957-1986: Incidence, Treatment and Outcome. British Journal of Surgery, 80, 502-504. http://dx.doi.org/10.1002/bjs.1800800433

[3] Hamilton, S.R. and Aaltonen, L.A. (2000) Pathology and Genetics of Tumours of the Digestive System. World Health Organization Classification of Tumours. International Agency for Research on Cancer Press.

[4] Kanthan, R., Saxena, A. and Kanthan, S.C. (2001) Goblet Cell Carcinoids of the Appendix: Immunophenotype and Ultrastructural Study. Archives of Pathology \& Laboratory Medicine, 125, 386-390.

[5] Burke, A.P., Sobin, L.H., Federspiel, B.H., Shekitka, K.M. and Helwig, E.B. (1990) Goblet Cell Carcinoids and Related Tumors of the Vermiform Appendix. American Journal of Clinical Pathology, 94, 27-35.

[6] Anderson, N.H., Somerville, J.E., Johnston, C.F., Hayes, D.M., Buchanan, K.D. and Sloan, J.M. (1991) Appendiceal Goblet Cell Carcinoids: A Clinicopathological and Immunohistochemical Study. Histopathology, 18, 61-65. http://dx.doi.org/10.1111/j.1365-2559.1991.tb00815.x

[7] Nitecki, S.S., Wolff, B.G., Schlinkert, R. and Sarr, M.G. (1994) The Natural History of Surgically Treated Primary Adenocarcinoma of the Appendix. Annals of Surgery, 219, 51-57. http://dx.doi.org/10.1097/00000658-199401000-00009 
Scientific Research Publishing (SCIRP) is one of the largest Open Access journal publishers. It is currently publishing more than 200 open access, online, peer-reviewed journals covering a wide range of academic disciplines. SCIRP serves the worldwide academic communities and contributes to the progress and application of science with its publication.

Other selected journals from SCIRP are listed as below. Submit your manuscript to us via either submit@scirp.org or Online Submission Portal.
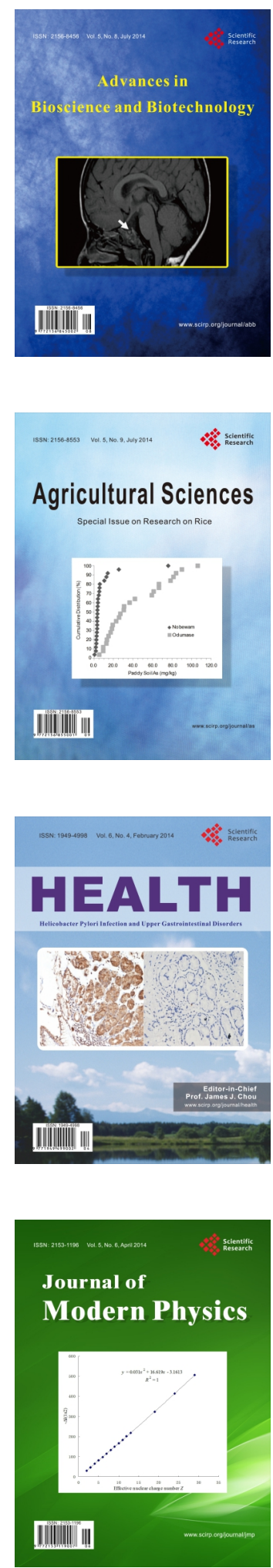
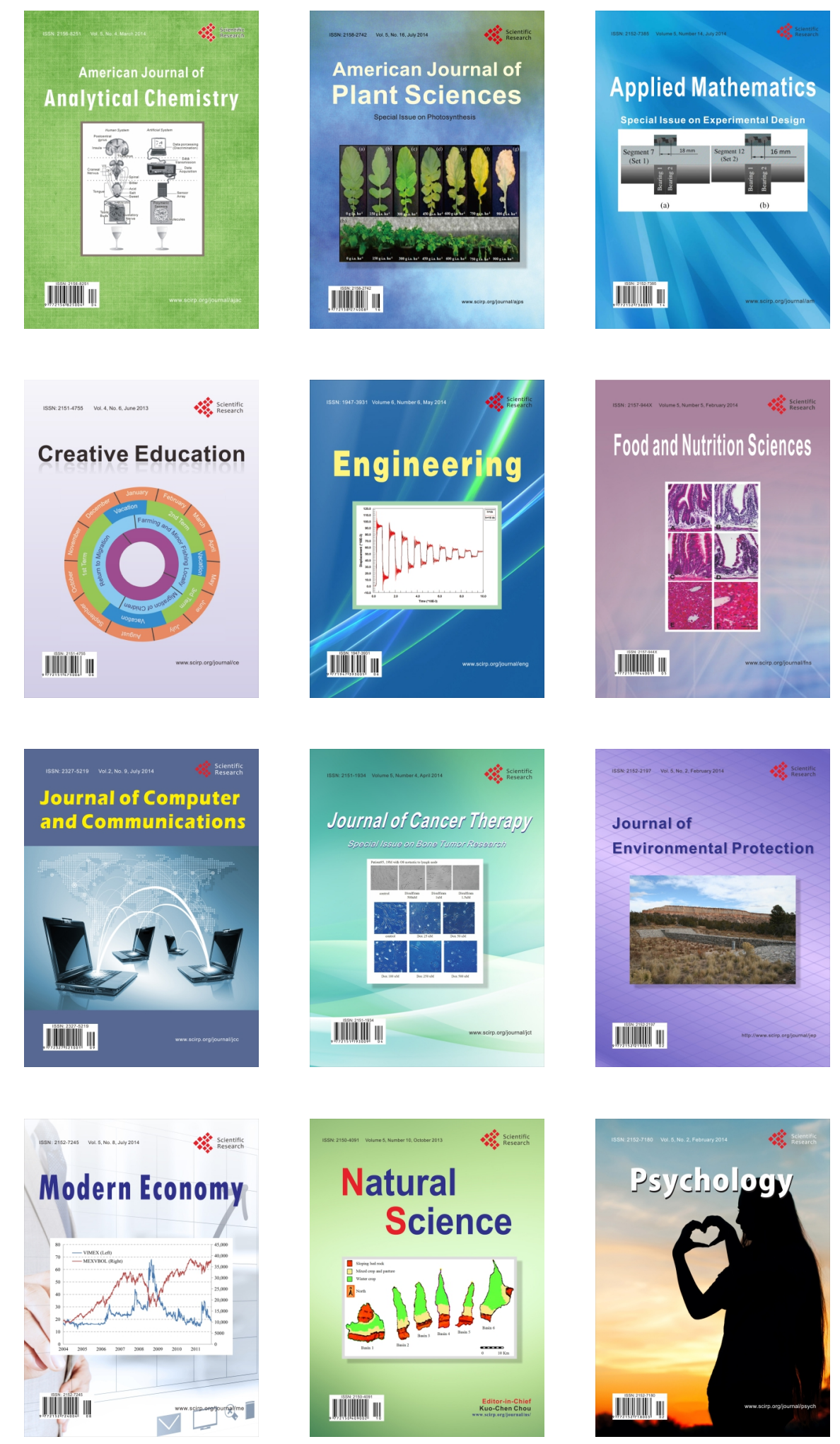